\title{
Which IP Strategies Do Young Highly Innovative Firms Choose
}

\author{
Veugelers, Reinhilde; Schneider, Cédric
}

Document Version

Accepted author manuscript

Published in:

Small Business Economics

DOI:

10.1007/s11187-017-9898-y

Publication date:

2018

License

Unspecified

Citation for published version (APA):

Veugelers, R., \& Schneider, C. (2018). Which IP Strategies Do Young Highly Innovative Firms Choose. Small Business Economics, 50(1), 113-129. https://doi.org/10.1007/s11187-017-9898-y

Link to publication in CBS Research Portal

\section{General rights}

Copyright and moral rights for the publications made accessible in the public portal are retained by the authors and/or other copyright owners and it is a condition of accessing publications that users recognise and abide by the legal requirements associated with these rights.

Take down policy

If you believe that this document breaches copyright please contact us (research.lib@cbs.dk) providing details, and we will remove access to the work immediately and investigate your claim. 


\title{
Which IP Strategies Do Young Highly Innovative Firms Choose
} Reinhilde Veugelers and Cédric Schneider

\author{
Journal article (Accepted version*)
}

\section{Please cite this article as:}

Veugelers, R., \& Schneider, 〔. (2018). Which IP Strategies Do Young Highly Innovative Firms Choose. Small Business Economics, 50(1), 113-129. 001: 10.1007/s11187-017-9898-y

This is a post-peer-review, pre-copyedit version of an article published in Small Business Economics. The final authenticated version is available online at:

\author{
DOI: https://doi.org/10.1007/s11187-017-9898-y
}

* This version of the article has been accepted for publication and undergone full peer review but has not been through the copyediting, typesetting, pagination and proofreading process, which may lead to differences between this version and the publisher's final version AKA Version of Record.

Uploaded to CBS Research Portal: May २०19 


\title{
Which IP strategies do young highly innovative firms choose?
}

Reinhilde Veugelers ${ }^{\circ}$ and Cédric Schneider ${ }^{\circ}$

- KULeuven, Bruegel and CEPR

${ }^{\circ}$ Copenhagen Business School

\begin{abstract}
This paper describes and analyzes the strategies of young highly innovative companies to appropriate the returns from their innovations. Upon controlling for other firm and industry characteristics, we show that firms combining a young age and small scale with a high $R \& D$ intensive profile are more likely to use IP, specifically combining formal and informal appropriation mechanisms. They are especially more likely to choose secrecy in combination with formal IP. This holds primarily when they introduce more radical innovations new to the market.
\end{abstract}

Keywords: Young Innovative Companies, appropriability, patents, secrecy

JEL-Classification: G24, O31, O38

Acknowledgment: The authors wish to thank the participants at the conferences and seminars at Brussels, Leuven, Mannheim, Copenhagen, Evora (EARIE 2013), Chicago (IIOS 2013). Veugelers acknowledges the financial support received from KULeuven (GOA/12/003) and FWO Flanders (G.0825.12) 


\section{INTRODUCTION}

Although the bulk of corporate $\mathrm{R} \& \mathrm{D}$ is accounted for by established large corporations, young entrepreneurial firms have been responsible for introducing major innovations (e.g. Baumol, 2004). Although these young firms are often small, their profile is distinct from typical longer established small firms. Young firms are not encumbered by the fear of cannabilizing existing positions (Reinganum 1983; Henderson 1993) and are therefore more likely to introduce new disruptive innovations, compared to incumbent firms, be they large or small. With their more radical innovations these young companies create the scene for new products, technologies and markets, on which other firms can build further. Having young companies impeded to innovate, might thus have an important impact on an economy's overall innovative and growth performance. Understanding what the specific barriers are these young firms face, is therefore important, even if they are only a small fraction of the total population of innovating firms.

Perhaps the most often discussed barrier for young innovators is access to finance (e.g. Hall, 2005). But young innovative firms may also be disproportionally facing difficulties in appropriating the returns from their innovations. Being more financially constrained, the cost of building an intellectual property (IP) strategy may be too high for them. In addition, young firms may lack the critical scale and resources to control complementary downstream assets needed to produce and commercialize the innovation. Such control becomes pivotal for appropriation when IP regimes are weak (Teece, 1986; Gans, Hsu \& Stern, 2002).

Young innovators often specialize in knowledge production and for these firms IP is vital as most of their critical assets are knowledge assets. These firms will need to use IP to certify their 
technological ability in the market for technology (Arora et al 2001). Likewise, IP is important when searching and negotiating with innovation and commercialization partners (Arora et al 2001). In addition, it may improve their access to much needed finance (e.g. Hsu and Ziedonis 2007; Haeussler et al 2014).

Despite the importance of young companies for the innovative growth performance of nations, despite the critical importance of IP for young innovators to appropriate the returns from their innovations, and the expected higher problems of young innovative firms when developing an IP strategy, there is surprisingly little analysis and evidence on the appropriability strategies of young innovative companies. This contribution tries to address the empirical gap.

In this paper we estimate a series of probability models to examine how young highly innovative firms appropriate the returns from their innovations differently from other innovating firms. The German part of the European-wide Community Innovation Survey administered by EUROSTAT (CIS) provides the data for our analysis. After controlling for firm and industry characteristics, we find that young highly innovative firms are more likely to choose both formal and informal appropriation mechanisms. They are particularly more likely to choose secrecy in combination with formal IP. This holds especially for young innovators when they introduce more radical innovations new to the market.

The paper is organized as follows. Section 2 gives the background. Section 3 describes the data and the methodology. Section 4 presents the results and Section 5 concludes. 


\section{BACKGROUND}

\subsection{How to appropriate the returns from innovation?}

The Resource Based View of the firm in the management literature holds that competitive advantage derives from a firm's ownership or control of "assets, capabilities, organizational processes, firm attributes, information, knowledge" that are valuable, rare, inimitable and nonsubstitutable. The ensuing rents must be protected by "isolating mechanisms" or "resource position barriers" (Wernerfelt, 1984; Rumelt, 1987; Barney, 1991). When the resource is knowledge, stateenforced property rights (patents, trademarks, copyright) and/or secrecy are typically identified as isolating mechanisms or position barriers that enhance the firm's bargaining power, and allow it to appropriate the value of its knowledge resources (Reitzig and Puranam, 2009).

Another strand in the strategy literature that deals with value appropriation asks the question who profits from innovation: the initial idea generator or others (Teece, 1986). In this literature, the strength of the IP regime is a crucial dimension for identifying whether the innovator can appropriate the returns from his ideas. The strength of the IP regime is considered to be exogenous to the firms: a tight IP environment is one where the innovator has an "iron clad patent or copyright protection, or where the nature of the product is such that trade secrets effectively deny imitators access to the relevant knowledge". Within a tight IP environment, the innovator is almost assured of translating its innovation into market value for some period of time. Even if the innovator does not possess the desirable endowment of complementary assets, the innovator can be successful as a specialized R\&D firm or will have, thanks to his iron clad protection of intellectual property, the ability and time to affordably access complementary assets. This does not need to be through ownership of the complementary assets; but this can be through contracting in or cooperation with providers. But IP regimes are seldom ironclad. In most cases, when IP regimes are not tight and 
when complementary assets need to be accessed to commercialize the innovation and these assets are highly specialized and not easily traded, the innovator needs control, typically through ownership, of the critical specialized assets, to appropriate the value of its innovation (Teece 1986).

Within the set of mechanisms to protect intellectual property, patents are the most marked and studied legal IP rights (see Griliches, 1984 and Hall et al, 2014, for a survey). The cross country and industry econometric studies on patenting show that there is a substantial heterogeneity in the propensity of firms to patent (see e.g. Pakes and Griliches (1984), De Rassenfosse \& van Pottelsberghe (2013)), particularly across sectors (Cohen et al., 2001; Cassiman \& Veugelers, 2002; Arundel, 2001; Hall et al., 2014). This reflects inter alia differences in the protection strength offered by patents across industries, being particularly high in "discrete" technologies such as pharmaceuticals where knowledge is well codified (Hall et al 2014).

The evidence available from various firm-level surveys (most notably the Yale and Community Innovation Surveys) shows not only the high variance in the propensity to patent across firms, even within industries, but that firms on average rely more on other modes to appropriate the value of their innovations rather than patents. Most notably secrecy and exploitation of lead time are found to be preferred forms of protection (Cohen et al., 2001; Arundel, 2001; Hall et al, 2014), again with the exception of pharmaceuticals and other chemicals where patents are still the favorite tool to secure the returns to $R \& D$. But even if patenting is not considered as the best form of protection in all cases, the use of patents remains widespread, as witnessed through the stream of applications at patent offices. Hall and Ziedonis (2001) call this gap between the rated relative ineffectiveness of patents in surveys and their widespread use, the "patent paradox".

Other legal IP rights beyond patents include trademarks and copyrights. The creation of a new trade mark may enhance the perceived value of innovative products by consumers, and increase their 
loyalty to the pioneering brand. Trademarks and patents thus constitute two distinct means to appropriate the benefits of innovation, whose effects are likely to be interrelated, as substitute protection modes, but also possibly as complements. A few papers test empirically the relationship between patents and trademarks at the level of the firm but considering them as proxies for respectively technological and marketing investments (von Graevenitz and Sandner, 2009; Schwiebacher and Muller, 2009). They do not consider them as complementary or substitute modes to appropriate returns from innovation. Millot and Llerena (2012) examine the latter relationship and find on a set of French publicly traded firms, that patents and trademarks are used in complementary fashion in life sciences (pharmaceutical products and health services), but as substitutes in the ICT sector (computer, electronic and optical products and electrical equipment). Somaya and Graham (2006) employ litigation data on patents, copyrights, and trademarks to study overlapping IP protections used by software firms and find evidence of joint use of different types of IP used by software firms, which they explain by economies of scale in organizational resources deployed for IP management.

The choice between patents and secrecy as substitute appropriation modes has received particular attention in the micro-economic theory literature. Anton and Yao (2004) and Encaoua and Lefouilli (2004) both consider the choice between these two mechanisms depending on the patent strength, the cost of imitation and the innovation size. A common thread in both models is that weak property rights imply disclosure incentives that are relatively stronger for smaller innovations. For a small innovation relative to the status quo technology, even a relatively weak patent will discourage imitation because the gain to using the new knowledge is insufficient to justify a possible infringement payment. Bigger, more radical, innovations are protected more through secrecy as a response to the bigger problem of imitation by a competitor. 


\subsection{How young firms appropriate the returns from innovations}

The literature on how to appropriate the returns from innovation (section 2.1) does typically not discuss the position of young innovators. Although young innovators are typically also small, what differentiates them most from other innovators, including traditional small firms, is their young age, lacking vested positions, retained earnings, experience and reputation. Being un-incumbent makes them more likely to introduce more radical big innovators (Henderson (1993); Henderson \& Clark (1990)). But are young firms relatively disadvantaged compared to incumbents in appropriating the value of their innovations? And are young innovators more likely to choose different modes to appropriate the value of their innovations? The literature is surprisingly un-explicit on this. It nevertheless provides some useful insights to address the question.

A point identified in the literature is that for young innovators, IP plays a more critical role compared to established companies. According to the Teece (1986) framework, being able to control their technological knowhow will be disproportionately important to young innovating firms, as they typically lack control over complementary assets. A young innovating firm typically does not (yet) possess the relevant specialized and co-specialized complementary assets. "The patents held by a small, technologically oriented firm may be its most marketable asset" (Levin et al. 1987, p. 797).

In the Teece (1986) framework, control of technological knowhow is associated with strong IP regimes. In this framework, the strength of the IP regime is determined by the efficacy of legal mechanisms of protection (patents, trademarks) and by the nature of technology, identifying the scope for secrecy. In both cases the strength of the IP regime is considered to be largely exogenous to the firm. When IP regimes are tight, the young innovative firm can avoid expensing to build or acquire ownership over the necessary complementary assets. Its IP will give it a strong bargaining 
chip to contract these assets, if available, or cooperate with others better positioned to provide such assets. Beyond helping young firms to protect their innovations from imitation or to access complementary assets for their innovations, strong IP regimes also facilitate the licensing or sale of IP protected know-how by the young firm, due to smaller transactions costs when operating on the market for technology. A stronger IP system thus facilitates activities of small firms specializing in technological know-how. Hall and Ziedonis (2001) argue that the US pro-patent policy in the eighties contributed to an increasing number of specialized technology firms focusing on semiconductor design. This is also the case for dedicated biotech firms. Such 'division of innovative labor' is closely related to growing technology markets in high-tech industries (Arora et al., 2001).

Beyond pinpointing the importance of IP for young innovators, the literature also provides some indication on which IP protection modes would work better for young firms, providing a stronger control on technological know-how. The models of Anton \& Yao (2004) and Encaoua \& Lefouille (2004) discussed supra, would suggest that young firms to the extent they are more likely to introduce important big radical innovations compared to the more incremental follow-on innovations by incumbents, would have a stronger preference for secrecy over patents.

Building an IP portfolio will be expensive. For young firms, being cash constrained and faced with difficulties in accessing external finance, this may constitute a barrier for developing an effective IP strategy. The high costs of patenting are well documented (e.g. van Pottelsberghe and François, 2009). A firm not only has to meet the direct monetary expenses associated with the application process but it also has to monitor the market for potential infringement and take legal action if needed. While the application costs are particularly high in Europe relative to the US, in the US the legal enforcement costs associated with IP can be substantial (van Pottelsberghe and François, 2009). 


\subsection{Evidence on appropriation strategies for innovation by young firms}

Although the literature clearly shows the importance of IP in determining how much value the innovator can capture, and although the literature hints at how this may hold differently for young innovative firms, there is surprisingly little empirical analysis on the specific IP strategies of young innovative firms.

The literature that looks specially at young innovative firms, typically looks at their likelihood of entry, their post-entry innovative performance and growth (e.g. Santarelli and Vivarelli, 2007; Acs and Audretsch, 1988) and the nature of the innovations they introduce. This literature by and large confirms that young innovators are more likely to introduce more novel, radical innovations (Schneider \& Veugelers, 2010). Less is known on the IP strategies used by these young innovators.

The empirical literature provides some scattered evidence on the critical use of patents for firms at start-up stage. The 2008 Berkeley Patent Survey on 1,332 high-tech start-ups founded in the US since 1998 provides interesting evidence of start-up patenting (Graham et al., 2010). A first finding is the different propensity to patent for start-ups across industries. While for bio-tech start-ups, patenting is a vital part of corporate strategy, firms in software try to avoid the patent system. The most important reason cited by startups for not patenting is cost, confirming the financial constraints for young firms (Graham et al. 2010). However, bio-tech firms rate concerns about the disclosure of information contained in a patent publication as a greater obstacle than costs. This is reminiscent of the importance of secrecy for the bigger innovations from bio-tech firms (Anton \& Yao (2004) and Encaoua \& Lefouille). They also point out that start-ups value the reputation effect that patent ownership may bring about, helping them in their transactions with other complementary firms or financiers. Particularly the latter access to finance effect from patenting for start-ups has been studied (e.g. Shane (2001), Lerner (1994), Hsu \& Ziedonis (2007), Mann and Sager (2007), 
Haussler, Harhoff \& Mueller (2012)), confirming that patents acts as a "signal" of proficiency and innovativeness, allowing bigger and faster venture capital funding.

The available evidence confirms the critical and specific importance of IP. However, most of this evidence is on patents and for start-ups. Less is known on which other types of IP strategies young firms might use beyond start-up stage. There is however some empirical evidence that looks at the use of different IP modes for small sized innovators, which young firms typically are. Arundel (2001), using the Eurostat Community Innovation Survey I for six EU countries, found that the propensity to patent rises with size, other things equal (see also Hall et al. 2014). When looking at the different IP modes, firms are found to systematically regard lead-time and secrecy as more important ways to protect their IP than patents. This holds across different size classes, but is stronger for smaller firms: smaller firms regard secrecy as even more important than larger companies. Leiponen et al. (2009) using an ad hoc survey of 936 Finnish SMEs also finds that small firms find informal means of protection, such as speed to market or secrecy, more important than patenting. Only dedicated research SMEs rank patents as the most important method of appropriating innovation returns in their field. Also Hall et al (2013), using UK CIS data, find that the informal to formal preference decreases with firm size.

All this evidence is supportive of secrecy being relatively more important at small firm size. Although young firms will typically also be small and face similar barriers as small innovators, related to a smaller critical scale and barriers to finance, they also face specific barriers related to their young age, such as lack of reputation and experience. At the same time, young firms are less encumbered by protecting existing positions, which makes them more likely to introduce radical rather than incremental innovations, which may require different IP strategies. These different 
barriers and incentives for young innovators call for specific evidence on IP strategies used by young innovators, differently from small innovators.

\subsection{Our contribution}

Despite the well-argued case of the importance of IP strategies for young firms and the evidence on differences in IP modes used by small firms, the issue of whether young innovative firms differ in their IP strategies is, as far as we are aware of, not empirically investigated. Using EUROSTAT Community Innovation Survey data for Germany, which has information on the use and effectiveness rating of various IP modes as well as the age of the innovators, we try to empirically address this evidence gap ${ }^{1}$.

More particularly we will investigate differences in the IP strategies between young small high R\&D intensive firms and other innovators. In a first stage, we will look at any difference in the use of an appropriation strategy in general. Can we confirm, consistent with the Teece (1986) framework that young firms are more likely to have a well-developed IP strategy to appropriate returns from their innovations? In a second stage, we will look at differences in which IP modes are used for appropriating the returns from innovation. Can we confirm in line with Anton \& Yao (2004) and Encaoua \& Lefouilli (2004) that young innovators are more likely to use informal secrecy modes rather than formal patenting modes, particularly when they introduce more radical bigger innovations?

Our main research questions are:

\footnotetext{
${ }^{1}$ The age of the firm is unfortunately not mandatory in the EUROSTAT EU wide organized CIS survey. Only a few participating countries, among which Germany, include this information in the questionnaire.
} 
- Would young innovators be more likely to have an IP strategy to protect their knowledge assets, which are often their only or major assets?

- Would young innovators have more incentives to build an IP portfolio combining different IP mechanisms to protect their knowledge assets? Or would they find it more difficult to do so, in view of their lack of funding?

- Would young innovative firms rely more on legally enforceable IP (like patents, trademarks and copyrights)? Or would they, with their ambitions for major inventions, prefer informal IP (secrecy), like in the Anton \& Yao (2004) and Encaoua \& Lefouilli (2004) models?

When looking at the specific IP profile of young innovative firms, we will particularly look at those that specialize as technology providers, focusing their activities on $\mathrm{R} \& \mathrm{D}$, as these are more likely to rely on IP. We will also look specifically at those firms that introduce more important bigger more radical innovations, as these are more likely to prefer secrecy over legal protection.

We control for other factors that may drive the choice of IP strategy. A most important control is sector or technology specificity, as the existing empirical literature strongly shows the strength of the IP regime to be sector/technology specific. The theoretical literature also points to correcting for the nature of the innovative activities, particularly its level of risk and probability to deliver important inventions. We also control for the extent to which the firm is financially constrained, as this may be a major impediment for firms to develop a costly IP strategy. To proxy for access to complementary assets, we use the extent to which firms rate access to partners for cooperation are a barrier for innovation. We will control for group membership. Those that are part of a larger group can use the IP expertise of the group and their access to finance, and thus may find it easier to build a full IP strategy. They may however also have less need for an IP strategy, if the group provides access to complementary assets as alternative mode to appropriate returns from innovation.

As we want to single out young highly innovative firms as a distinct group of innovators, we want to differentiate them from small firms in general. This is why we also control for firm size. 
Similarly we control for firm age in general and for R\&D intensity. This will allow us to looking at the extra effect for those firms that combine a young, small and high R\&D profile, beyond a mere age or scale or R\&D intensity effect. This extra effect we will label as the YICs effect (see also Schneider \& Veugelers (2010)).

Our results strongly support that after correcting for other factors, firms that combine a young and small high R\&D intensive profile, are more likely to use an IP strategy, particularly combining both formal and informal IP mechanisms. Within the portfolio of IP mechanisms, the YICs effect plays strongest on the secrecy mode. Further analysis shows that the YICs effect for the use of secrecy in combination with formal IP plays more significantly for those YICs with big, more radical, innovations.

\section{DATA AND METHODOLOGY}

\subsection{Sample}

The data used stem from the German part of the Community Innovation Survey (CIS) conducted by EUROSTAT in European Union Member States in 2005 (CIS-IV) ${ }^{2 .}{ }^{3.4}$. EUROSTAT-CIS survey data are by now a standard data source used for innovation econometrics at the firm level. Mairesse \& Mohnen (2010) provide a review of the studies using CIS data and a discussion of the strengths and weaknesses of the data.

\footnotetext{
2 The survey is conducted annually by the Centre for European Economic Research (ZEW), infas Institut fuer Sozialforschung and ISI Fraunhofer Institute on behalf of the German Federal Ministry of Education and Research. A detailed description of the survey data and the sampling method can be found in the background reports available at ZEW (www.zew.de).

3 The survey is directed to a stratified sample of companies in manufacturing and services sectors with at least 5 employees. Although the very small firms are not targeted, the sample nevertheless contains 5\% of firms with less than 5 employees.

4 We restrict attention to West German firms only, dropping East German observations to avoid a source of heterogeneity that is outside our issues of interest.
} 
The CIS survey addresses the innovation strategies of firms, covering quantitative information on innovation personnel and budgets as well as qualitative information on the type of innovation strategy being used. In addition, the survey contains information on respondent's motives for innovation, perceptions of innovation barriers and use and effectiveness of appropriation strategies. Lastly, the survey contains quantitative information on the firm, such as sales, age and employment. It also includes the share of sales due to innovations, as a measure of innovation success. The rich set of variables included in the CIS survey make it therefore a good dataset to study the research question at hand. Although the dataset is rich in variables, its main restriction is the cross-section nature of the dataset, limiting the construction of valid control variables and leading to issues of endogenity due to unobserved heterogeneity. We will estimate a series of probability models to explore the appropriation choices of YICs, and our results should therefore be interpreted as correlations, rather than being causal.

The cross-sectional nature of our dataset also affects our analysis by an evident survivorship/selection bias. Indeed, due to the nature of the data, we are not only excluding the vast majority of young firms that failed in the very early stages of their life, but also, among the surviving young firms, we focus on those that, being highly innovative, are the most virtuous.

Another drawback of the data is that it only includes information at the consolidated firm level, aggregating across projects within the firm. For the remainder of our analysis, we focus on innovation active firms, as most of our variables of interest are only available for these firms. 


\subsection{Variables and empirical methodology}

\subsubsection{Defining and characterizing YICs}

We empirically characterize young highly innovative companies through a $\mathbf{Y I C}$ dummy. Firms qualify for YIC status using an (extended) EU State Aid definition: an innovation active company needs to be less than 10 years old, have less than 250 employees and spend at least $10 \%$ of its revenues on $R \& D^{5}$.

Out of our sample of 1393 innovation-active companies, only 103 companies qualify for the YICs status using the (extended) EU State Aid definition, representing only $7.4 \%$ of all innovation-active sample companies. Table 1a shows that YICs are overrepresented in the following sectors: Research, development and engineering (24\%), ICT services (23\%) and Electrical, medical and optical instruments (23\%). Biotechnology is not so frequent in the German innovation landscape as compared to the US. Somewhat less than half of the YICs are part of a group ${ }^{6}$.

\section{Table 1a: Industry classification}

Table $1 \mathrm{~b}$ shows that YICs are on average almost 6 years old and employ about 25 people. It is important to note that the sampling strategy does not pick up the very early stage of company formation. The YICs we will be studying are therefore already beyond the initial birth stage and should therefore not be considered as early start-ups, but rather as young firms.

\footnotetext{
${ }^{5}$ Young Innovative Enterprises are defined in the EU State Aid Rules as small Enterprises, less than 6 years old, having being "certified' by external experts on the basis of a business plan, as capable of developing products or processes which are technologically new or substantially improved and which carry a risk of technological or commercial failure, or have R\&D intensity of at least $15 \%$ in the last three years or currently (for start-ups). However, there are only 51 YICs in our sample when applying this definition. We therefore expand the R\&D and age criteria in order to garner more observations. Schneider and Veugelers (2009) show that the innovative profile of YICs does not change substantially with small extensions of these criteria.
}

\footnotetext{
${ }^{6}$ These could be corporate spinoffs, or independent start-ups which have been acquired in the past. Unfortunately, the CIS survey does not contain information on the corporate history.
} 


\section{Table 1b: Characterizing YICs}

YICs tend on average to specialize on $R \& D$ with an average R\&D intensity of $73 \%$. But this average reflects two types of firms, some which are specialising in $R \& D$ and others, as the high standard error indicates. The median R\&D intensity value is $23 \%$. We will check for differences between High R\&D YICs, i.e. those with R\&D expenditures above the median YICs value and the Low R\&D YICs.

Compared to other innovators, YICs are more likely to introduce innovations that are new to the firm and even more so for innovations that are new to the market. In our empirical analysis we want to single out firms with bigger, more radical, innovations, which we proxy through those that introduce product innovations that are new to the market. To do so we construct a dummy variable BigInnov, which takes the value one if the firm has introduced a market novelty. These firms account for $52 \%$ of our sample firms. Within the group of YICs, a larger share, $65 \%$ introduced innovations new to the market (BigInnovYICs)

Although splitting YICs according to whether they specialize in R\&D and have big innovations allows for interesting hypotheses testing, the small overall number of YICs in the sample limits splitting exercises.

\subsubsection{Appropriation strategies}

In line with Hall et al (2012), we empirically distinguish formal IP and informal appropriation mechanisms shaping a firm's ability to exploit its knowledge. The main forms of formal IP are patents, trademarks, designs and copyright. Secrecy, lead time, and complexity are subsumed under the informal IP heading. We define formal appropriability as a dummy variable that takes on the value one if the focal firm applied for a patent, utility patent, design, trademark or for copyright 
protection. Conversely, we define informal appropriability as a binary variable equal to one if firms used secrecy, complexity or lead time as means of protection. Although the survey contains information not only on actual use of IP mechanisms, but also on how the firms rate the importance of the various IP mechanisms, the main analysis will focus mostly on the use, as this is much less prone to subjectivity bias.

\subsubsection{Control variables}

As our main question of interest is whether young innovative firms differ in their appropriation strategy, we include a set of control variables to net out any potentially confounding factors.

First, we include the size of the focal firm, measured by the logarithm of employment, and the logarithm of firm age. We also control for the input of R\&D resources into the firm's innovative process, measured by the ratio of (intramural) R\&D expenditures to sales (R\&D intensity). Since we control for age, size and R\&D intensity, a significant positive YICs coefficient would signal that after controlling for the effect of being small or young or highly $R \& D$ intensive, those firms that combine all three characteristics, are more or less likely to use any appropriation strategy. This extra effect we will label as the YICs effect.

We control for the riskiness of the innovation process by using a survey measure that captures the firm's rating of importance of high risk as an obstacle to innovation (see Cassiman and Veugelers, 2002). Risk typically characterizes an innovation strategy which goes for important "big" innovations or breakthroughs in contrast to a low risk road of small, incremental innovations. We also include a variable that captures the basicness of the firms' $R \& D$, measured as the firm's rating of importance of information from public research institutes and universities relative to the importance of customers and suppliers as an information source (Cassiman and Veugelers, 2002; 2006). More basic R\&D increases the risk of the innovation process. 
The lack of access to external finance may limit the firm's ability to develop an IP strategy. But at the same time, it may operate as a motive for young and small firms to resort to formal means of protection such as patents that may have a certification function and facilitate access to external funding. We control for the lack of external finance by using a measure for the firm's rating of lack of external finance as an obstacle to innovation. (Subsidy Variable?)

Firms that lack complementary resources and skills to bring their innovations to market, will need to go to the market to access these resources or skills, either by acquiring ownership or by forging partnerships. For these firms, IP will be important to reduce transaction costs and improve their bargaining position. We use the perceived difficulty of finding cooperation partners as a barrier to innovation to proxy for firms that lack complementary assets (coop partners). Difficulty of finding qualified personnel?

\section{EXPORT}

\section{Acquisition of innovative machinery and equipment}

Since the scaling for the variables which use scores of the respondents on factors as impediments to innovation may vary across firms, we convert the survey scores (from the zero to three scale) to normalized $z$-scores such that each variable has a mean of zero and a standard deviation of one. As all of these scoring variables suffer from a possible subjectivity bias, they need to be handled with care.

Finally, we include a dummy for firms that are part of a group (Group), 14 sector dummies that were constructed based on their NACE codes, a nomenclature of economic activities in the European Community and eleven regional dummies based on the State in which the firm is located. 


\subsubsection{Empirical methodology}

We estimate a series of probability models to explore the appropriation choices of YICs. We first consider a probit model of whether firms are more likely to choose any type of appropriation mechanism (coded as 1) or none (coded as zero). Next, we distinguish between two types of appropriation mechanism: formal (patent, utility model, trademark, copyright or design) and informal (secrecy, complexity or lead time). We model this (non-exclusive) choice using a bivariate probit model that takes into account correlations between the residuals of the two types of appropriation measures. We also make multinomial (exclusive) comparisons to investigate whether firms are more or less likely to combine formal and informal appropriation strategies rather than to exclusive use one or the other type of appropriation strategy or none. We use a multinomial logit model of appropriation choice where we define four categories: no appropriation, formal appropriation only, strategic appropriation only, or both. Finally, we look at the 4 most important individual IP modes: patents, trademarks, secrecy and lead time. We run multivariate probit models that allow us to model each of the 4 appropriation choices in separate equations, but taking their correlation into account.

A fully fledged analysis of complementarity of IP strategies is beyond the scope of the analysis in view of the data at hand. Our data only allow looking at the combination of IP strategies at the firm level and not at the invention level. We also cannot assess complementarity using a productivity analysis, i.e. checking whether firms that combine IP strategies will be more successful compared to those firms that use single IP strategies, as we are lacking any good performance measure for the value capture capacity from IP strategies. 


\section{RESULTS}

\subsection{Descriptive analysis}

\subsubsection{YICs and appropriation strategies}

The descriptive statistics in Table 2a show a significantly higher reported use of appropriation strategies by YICs as compared to other innovators ${ }^{7}$. This holds particularly and is highly significant for the use of informal protection mechanisms, particularly secrecy and lead time. On the use of formal protection mechanisms, YICs display no significant different use with respect to patents and copyrights. But there are significantly more active in using trademarks and utility models.

\section{Table 2a: YICs and appropriation strategies - use}

When looking at the use of both informal and formal protection mechanisms simultaneously (Table 2b), we find YICs to be significantly less present in the "no protection" case. They are less relying on "only formal" protection mechanisms, but they are significantly more combining both formal and informal protection mechanisms. This suggests a higher importance for informal protection, but in combination with legal mechanisms, thus supporting the complementary use of informal and formal protection mechanisms for YICs, an issue which we will be exploring in more depth in the econometric analysis.

\footnotetext{
${ }^{7}$ The CIS questionnaire also asks respondents to rate the various appropriation mechanisms on their importance. These results show that there are no strongly significant differences in the reported importance of informal mechanisms for appropriating returns between YICs and other innovators, conditional on the mechanisms being used. The difference seems therefore only reflected in whether they use mechanisms or not. In the remainder of the analysis we will only look at whether or not mechanisms have been used, rather than on how important mechanisms were rated by the respondents.
} 
Table 2b: YICs and appropriation strategies: combining formal and informal

\subsubsection{Control variables}

Table 3 looks at the differences between YICs and other innovators on the control variables capturing various dimensions of the innovation process.

\section{Table 3: Innovation Profile of YICs}

YICs score higher on riskiness and basicness, confirming their early stage high uncertainty innovative profile with more scope for important inventions. They experience a significantly higher lack of external funding, reflecting their higher financial constraints. YICs rate the search for partnerships as a more critical obstacle as compared to other innovators. This is consistent with them lacking complementary assets, for which they need to look for partners.

\subsection{Econometric results}

\subsubsection{YICs and IP}

Table $4 \mathrm{a}$ reports the marginal effects of a probit model where the dependent variable takes the value one if the sample firm used any type of appropriation strategy. The results show that the most significant determinants of appropriation use are the size of the firm, the basicness and riskiness of the firm's innovation profile and if the firm is part of a group: large firms, firms being part of a group, firms with a more basic $\mathrm{R} \& \mathrm{D}$ profile and firms with a more risky $\mathrm{R} \& \mathrm{D}$ profile are more likely to be using an appropriation strategy.

When controlling for the effect of firm size, age and R\&D intensity, firms combining a small, young and high R\&D profile (the YICs effect), are more likely to use an appropriation strategy (col. $1)$. 
Once we also control for the nature of the innovation strategy (col 2-3), particularly their riskiness and basicness, the YICs effect no longer is significant, suggesting it is the higher risk profile of YICs which makes them more prone to use an appropriation strategy. The perceived lack of external finance does not play out significantly in the use of appropriation strategies, probably as this construct, although having high values, does not differ much among the sample firms.

Columns (3) and (4) split the YICs according to their R\&D intensity (above or below the median). The results show that the YICs effect holds only for those YICs with high R\&D intensities, while there is no significant YICs effect for those YICs with lower R\&D intensities. This is consistent with the view that appropriability is particularly important for YICs specializing as technological know-how firms.

\section{Table 4a: Probit models of appropriation choice}

The bivariate probit analysis looks at the probability of using formal mechanisms versus informal ones to appropriate the returns from innovation. The bivariate probit model takes into account any correlation between formal and informal protection. Table $4 \mathrm{~b}$ reports the marginal success probability for each equation. The results confirm that the use of different types of appropriation is indeed correlated, even after correcting for determining factors, suggesting that both strategies are complementary at the firm level.

Larger firms, more R\&D intensive firms and firms part of a group are more likely to use formal mechanisms as well as informal mechanisms. Younger firms are also more likely to use both formal and informal mechanisms, but the age effect is not significant. The riskiness of the innovation, while being non-significant for formal protection, increases the odds of using informal mechanisms. This is consistent with riskiness, being associated with a higher probability of major inventions, to 
favor secrecy, as in the Anton \& Yao (2004) and Encaoua \& Lefouilli (2004) models. The more firms need to find cooperative partners, the more likely they will use formal IP mechanisms.

After correcting for these firm characteristics, YICs which combine a young age, with a small size and a high R\&D intensity, are found to be significantly more likely to use formal as well as informal protection mechanisms. We thus have a significant YICs effect in the choice of both formal and informal IP mechanisms, with the marginal effects for both choices being of similar size.

\section{Table 4b: Bivariate probit - Formal and informal IP mechanisms}

As formal and informal protection mechanisms are so closely aligned at the firm level, we test in a multinomial specification the probability of using a combination of formal and informal mechanisms, compared to the cases of an exclusive use of formal or informal mechanism. In Table $4 \mathrm{c}$ we show the change in probability of each outcome type induced by a change in the right-hand side variable, holding all other variables constant, so the rows sum to zero. This multinomial analysis confirms that large, $R \& D$ intensive and group member firms are more likely to combine formal and informal appropriation mechanisms. Also firms in need of cooperation partners are significantly more likely to use a combination of formal and informal mechanisms. On top of these effects, we find a significant YICs effect, as firms that combine a young, small and high R\&D intensive profile are more likely to choose a combination of formal and informal mechanisms.

\section{Table 4c: Multinomial logit model of appropriation choice}

All these results so far indicate a significant YICs effect, as the firms combining a young age with a small size and a highly innovative profile are more likely to use a full appropriation strategy, combining formal and informal protection mechanisms. 


\subsubsection{Individual IP modes}

We continue the analysis by looking at the most important individual protection mechanisms: patents, secrecy, lead time and trademarks. We look at these 4 choices in a multivariate probit. $^{8}$ The results clearly indicate the need to consider these choices encompassing, as all pairwise correlations are significant. Table $5 \mathrm{a}$ reports the estimation results and Table $5 \mathrm{~b}$ the change in predicted probabilities as the YICs dummy changes from zero to one. ${ }^{9}$

Large firms and more R\&D intensive firms are more likely to choose patents, secrecy, lead time as well as trademarks. Age again has no significant effect, except for young firms being more likely to choose lead time. On top of these effects, firms that combine a young, small and R\&D intensive profile are more likely to use secrecy. The YICs effect is also present for the use of lead time, the other informal protection mechanism, but this effect is only significant at the $10 \%$ level. With respect to formal mechanisms, there is no YICs effect for patents. Only on trademarks, is there a positive effect, but only significant at the $10 \%$ level.

\section{Table 5a: Multivariate probit on appropriation mode choice}

When looking at individual IP modes, it is therefore particularly secrecy which stands out as the differential protection mode of use for young, small, highly innovative companies (see Table 5b). This would be consistent with the more important nature of their innovations, which would render secrecy more important as IP mode, as suggested by Anton \& Yao (2004) and Encaoua \& Lefouilli (2004). The next section will further explore this hypothesis.

\footnotetext{
${ }^{8}$ We estimate the 4-equation probit models by the method of simulated maximum likelihood, using the GewekeHajivassiliou-Keane (GHK) simulator to evaluate the 4-dimensional Normal integrals in the likelihood function (see e.g., Greene, 2000). We use 50 draws of random variates to calculate the simulated likelihood.

${ }^{9} \mathrm{We}$ do not report all marginal effects at this is computationally too intensive
} 


\section{Table 5b: Marginal effects of YICs on appropriation mode choice}

\subsubsection{YICs introducing big innovations: new to the market}

Would bigger innovations call for a different appropriation strategy and are YICs different in their appropriation strategy because they are more likely to be the "big" innovators? To test the Anton \& Yao (2004) and Encaoua \& Lefouilli (2004) prediction more closer, we will look at the size of the innovations introduced by the firms, as proxied by them introducing innovations new to the market (BigInnov and BigInnovYICs). Within the set of informal appropropriation modes, we will look at secrecy more particularly.

The bivariate probit analysis (Table 6a) shows that "big" innovators are more likely to choose secrecy, as well as formal protection, in line with the results for the overall sample. The secrecy effect is however less significant. This contrasts with YICs with big innovations new to the market, for which the secrecy effect is highly significant, while we find no such effect for other YICs. YICs with big innovations are also more likely to choose formal protection, but this effect is nonsignificant.

Table 6a: Bivariate probit - formal protection and secrecy; by size of the innovation

To look at the complementarity between formal protection and secrecy further, we use multinomial logit estimation for firms that report an appropriation mechanism, excluding those that do not use any appropriation method (Table 6b). The multinomial logit estimation shows that firms with bigger innovations are more likely to use secrecy in combination with formal protection. This holds particularly for YICs with big innovations. Our results therefore only partly support the theory predictions from Anton \& Yao (2004) and Encaoua \& Lefouilli (2004) that "big innovators", particularly young big innovators, are, more likely to resort to secrecy. But secrecy is not a 
substitute for formal protection. On the contrary, secrecy is deployed in complement with formal protection.

Table 6b. Multinomial model of appropriation choice of YICs: by "size of the innovation"

\section{CONCLUSIONS}

There is little analysis and evidence on the appropriability strategies of young innovative companies. This is particularly surprising given the importance of young companies for the innovative growth performance of nations and despite the specific barriers and incentives that young innovative firms face when developing an IP strategy. Using German CIS data, which has information on the use of various IP modes as well as the age of the innovators, we try to address this gap. We are particularly interested to see in line with the Teece (1986) framework, whether an IP strategy is more important for young innovative firms to control their knowledge assets, which are often their major assets. And with their ambitions for major inventions, would they prefer informal IP (secrecy) over formal IP (patents or trademarks), like in the Anton \& Yao (2004) and Encaoua \& Lefouilli (2004) models? When looking at young innovative firms, we single out those that specialize in $\mathrm{R} \& \mathrm{D}$, and those that introduce "big" innovations. We control for a whole range of other factors that may drive the choice of IP strategy, including technology specificity, the nature of the innovative activities and financial constraints.

Our results strongly support that after controlling for firm size, age and R\&D intensity, the additional effect of being simultaneously young, small and high $R \& D$ intensive is associated with a higher likelihood to use an IP strategy. The higher likelihood of YICs to use IP strategies holds most strongly for those YICs with specialize more on knowledge creation, in line with Teece (1986). 
When looking at the different IP modes, we find that YICs are particularly more likely to combine both formal and informal IP mechanisms. Innovators with big, new to the market innovations, are significantly more likely to complement formal IP protection with secrecy. This holds particularly for YICs with big innovations. This use of secrecy is in support of the Anton \& Yao (2004) and Encaoua \& Lefouilli (2004) models, but not as an alternative to formal protection, but as a complement.

Further research is clearly needed on this issue. First, extending the research to other countries would allow for more heterogeneity in the characteristics of the IP legislation. The availability of CIS-like information for other countries facilitates such cross-country comparisons. Extending the sample to include more observations for young innovators (without comprising their specific characteristics), would allow for more robust analyses of the heterogeneity within this subsample.

As empirical research at the firm level cannot tell whether different appropriation modes are used for different types of firm inventions, a useful complement to the firm level analysis is information at the invention level. This would allow looking at which IP mechanism is most suitable for which particular invention, particularly comparing more risky, radical, bigger inventions to the incremental smaller inventions.

The complementarity between various appropriation modes also deserves further analysis, in general and in particular for young innovative companies. Beyond assessing complementarity between IP modes from joint use, this analysis should be extended to a productivity analysis, i.e. checking whether a joint use of several appropriation mechanisms and which specific combinations leads to an enhanced appropriation of returns from innovation. 
Ultimately we are interested in how the differential use of IP mechanisms by firms translates into static and dynamic performance differences at the firm level and finally at the economy level. It would be particularly interesting to see whether the big innovations of young small R\&D intensive firms that combine formal and informal IP, including particularly secrecy, are also more likely to be successful for the firm. Such an analysis requires extending the survey data to performance measures, going beyond a cross-section analysis to properly tackle endogeneity issues. Even more challenging are the policy implications. If secrecy proves to be part of the best way for young innovators to appropriate the returns from their "bigger" inventions, how can this be squared with assuring positive technology spillovers on the wider community. A better understanding of the social versus private benefits from innovation requires a better understanding of the complementarity between the various IP modes chosen by the firm, i.e. how firms combine secrecy with patents and lead time. We hope we have contributed to making this research agenda more center stage.

\section{REFERENCES}

Acs, Z. J. and D. B. Audretsch (1988). "Innovation in Large and Small Firms: An Empirical Analysis", The American Economic Review , 78(4), 678-690.

Anton, J.J. and D. A. Yao, 2004, "Little patents and big secrets: managing intellectual property", Rand Journal of Economics, 35, 1-22

Arora, A., A. Fosfuri, and A. Gambardella. 2001. Markets for Technology: The Economics of Innovation and Corporate Strategy. Cambridge, MA: MIT Press.

Arundel, A., (2001). "The relative effectiveness of patents and secrecy for appropriation", Research Policy, 30 (4), 611-624.

Barney, J. (1991), "Firm Resources and sustained competitive advantage", Journal of Management, 17(1), 99-120. 
Baumol, W. (2004), "Education for Innovation: Entrepreneurial Breakthrough vs. Corporate Incremental Improvements", NBER Working Paper, No. 10578.

Cassiman, B. and Veugelers, R., (2002), "R\&D Cooperation and Spillovers: some empirical evidence from Belgium", American Economic Review, 92(4), 1169-1184.

Cohen, W., R. Nelson, and J. Walsh (2001). "Protecting Their Intellectual Assets: Appropriability Conditions and Why Firms Patent and Why They Do Not in the American Manufacturing Sector." NBER working paper 7552.

De Rassenfosse, G., \& Van Pottelsberghe de la Potterie, B. (2013). The role of fees in patent systems: Theory and evidence. Journal of Economic Surveys,27(4), 696-716.

Encaoua, D. and Lefouili, Y. (2005), "Choosing Intellectual Protection: Imitation, Patent Strength and licensing Agreement," Annales d'Economie et de Statistique, 79-80, 241-271.

Gans J.S., Hsu, D.H. and Stern, S. (2002), "When does start-up innovation spur the gale of creative destruction?" The RAND Journal of Economics, 33(4), 571-586

Greene, W.H. (2000), "Econometric Analysis", Fourth edition, Prentice-Hall International, Upper Saddle River NJ.

Graham, S. J. H., R. Merges, P. Samuelson, and T. Sichelman (2010), "High Technology Entrepreneurs and the Patent System: Results of the 2008 Berkeley Patent Survey", Berkeley Technology Law Journal 24(4): 1255-1328.

Griliches, Z. (Ed.) (1984), “ $R$ \& D, patents, and productivity”, University of Chicago Press: Chicago

Hall, B.H., (2005) "The Financing of Innovation," in Shane, S. (ed.), Blackwell Handbook of Technology and Innovation Management, Oxford: Blackwell Publishers, Ltd., 2005.

Hall, B. H. and A. Ziedonis (2001), "The Determinants of Patenting in the U. S. Semiconductor Industry, 1980-1994", Rand Journal of Economics, 32, 101-118.

Hall, B.H., C. Helmers, M. Rogers and V. Sena (2013), "The importance (or not) of patents to UK firms," Oxford Economic Papers, Oxford University Press, vol. 65(3), pages 603-629.

Hall B.H., C. Helmers, M. Rogers and V. Sena (2014), "The choice between formal and informal intellectual property: a review”, Journal of Economic Literature, vol. 52(2), pages 375-423

Haeussler, C. , D. Harhoff, and E. Mueller. (2014) "How patenting informs VC investors-The case of biotechnology." Research Policy 43: 1286-1298.

Henderson R. (1993). Underinvestment and incompetence as responses to radical innovation evidence from the photolithographic alignment equipment industry. RAND Journal of Economics 24(2): 248-270 
Henderson R, Clark K. (1990) Architectural innovation: The reconfiguration of existing product technologies and the failure of established firms. Administrative Science Quarterly 35(1): 930

Hsu D. H., and R.H. Ziedonis. (2007) "Patents as Quality Signals for Entrepreneurial Ventures", Academy of Management Best Paper Proceedings.

Leiponen, A. and J. Byma (2009), "If you cannot block, you better run: Small firms, cooperative innovation, and appropriation strategies", Research Policy 38: 1478-1488.

Lerner, J. (1994), “The importance of patent scope: an empirical analysis", Rand Journal of Economics, 25,2, 319-334.

Levin, R. C., A. K. Klevorick, R. R. Nelson and S. G. Winter (1987), "Appropriating the Returns from Industrial Research and Development." Brookings Papers on Economic Activity (3): 783-820.

Mairesse, J., \& Mohnen, P. (2010). Using innovation surveys for econometric analysis. Handbook of the Economics of Innovation, 2, 1129-1155.

Mann, R. J., and T. W. Sager (2007), "Patents, Venture Capital, and Software Startups" Research Policy 36: 193-208.

Millot, V. and P. Llerena (2012), "Are trademarks and patents complementary or substitute protection for innovation", Paper presented at the DRUID conference, Copenhagen, Denmark.

Pakes, A., Griliches, Z. (1984). "Patents and R\&D at the firm level: A first look". In: Griliches, Z. (Ed.), Research and Development, Patents and Productivity. The University of Chicago Press, USA, pp. 55-72.

Reitzig, M. \& P. Puranan, (2009), "Value appropriation as an organizational capability: the case of IP protection through patents", Strategic Management Journal, 30, 765-789.

Rumelt, R. P. (1987), 'Theory, strategy and entrepreneurship', in D. J. Teece (ed.), The Competitive Challenge, Strategies for Industrial Innovation and Renewal. Ballinger Publishing Company: Cambridge, pp. 137-159.

Santarelli, E. and M. Vivarelli (2007), "Entrepreneurship and the process of firms' entry, survival and growth", Industrial and Corporate Change, 16(3), 455-488

Schneider, C. and R. Veugelers (2010), "On Young Highly Innovative Companies: why they matter and how (not) to policy support them", Industrial and Corporate Change, 19(4).

Schwiebacher, F. and E. Müller, 2009, "How companies use different forms of IPR protection: Are patents and trademarks complements or substitutes?", Paper presented to the DRUID-DIME Academy Winter 2010 PhD Conference, Aalborg Denmark, January 21-23. 
Shane, S. (2001), "Technological opportunities and new firm creation", Management Science, 47 (2), 205-220.

Somaya, D. and S. Graham (2006), "Vermeers and Rembrandts in the same attic: Complementarity between copyrights and trademarks leveraging strategies in Software", Georgia Institute of Technology TIGER Working Paper.

Teece, D.J. (1986). "Profiting from Technological Innovation: Implications for Integration, Collaboration, Licensing, and Public Policy." Research Policy (6), 285-305.

von Graevenitz, G. and P. Sandner (2009), “Are advertising and R\&D Complements?”, Technical University Munich and Ludwig-Maximilians-Universität Munich (Germany), November 2009.

van Pottelsberghe de la Potterie B. and D. François (2009) "The cost factor in patent systems", The Journal of Industry, Competition and Trade, 9(4), 329-355.

Wernerfelt, B. (1984), “A resource-based view of the firm”, Strategic Management Journal, 5, 2, 171-180. 
Table 1a: Industry classification

\begin{tabular}{lrrrr} 
& \multicolumn{3}{c}{ Other Innovators } \\
\cline { 2 - 5 } & Yrequency & $\%$ & Frequency & $\%$ \\
\hline 1 Food and tobacco & 0 & 0.00 & 41 & 3.18 \\
2 Textiles and leather & 1 & 0.97 & 38 & 2.95 \\
3 Wood, paper, and publishing & 6 & 5.83 & 99 & 7.68 \\
4 Chemicals and petroleum & 8 & 7.77 & 150 & 11.64 \\
5 Glass, ceramics, and furnitures & 0 & 0.00 & 38 & 2.95 \\
6 Metal & 2 & 1.94 & 142 & 11.02 \\
7 Machinery and equipment & 2 & 1.94 & 134 & 10.40 \\
8 Electrical machinery, medical, and optical instruments & 24 & 23.30 & 179 & 13.89 \\
9 Motor vehicles & 4 & 3.88 & 49 & 3.80 \\
10 Sales of motor vehicles, wholesale, and retail trade & 1 & 0.97 & 65 & 5.04 \\
11 Transportation and communication & 1 & 0.97 & 76 & 5.90 \\
12 ICT & 24 & 23.30 & 73 & 5.66 \\
13 Research, experimental development and engineering & 25 & 24.27 & 77 & 5.97 \\
14 Consulting & 5 & 4.85 & 128 & 9.93 \\
\hline
\end{tabular}

Table 1b: Characterizing YICs

\begin{tabular}{|c|c|c|c|c|c|c|c|c|c|c|c|c|}
\hline & \multicolumn{4}{|c|}{ All innovators } & \multicolumn{4}{|c|}{ YICs } & \multicolumn{4}{|c|}{ Other innovators } \\
\hline & $\mathrm{N}$ & Mean & median & s.d. & $\mathrm{N}$ & Mean & median & s.d. & $\mathrm{N}$ & Mean & median & s.d. \\
\hline Age & 1393 & 35.5 & 20 & 37.6 & 103 & 5.8 & 5 & 2.4 & 1290 & 37.9 & 22 & 38.1 \\
\hline Employment & 1393 & 1228.8 & 85 & 9699.1 & 103 & 25.5 & 12 & 33.7 & 1290 & 1324.8 & 103 & 10072.9 \\
\hline R\&D intensity & 1393 & 0.108 & 0.033 & 0.877 & 103 & 0.731 & 0.231 & 3.146 & 1290 & 0.058 & 0.028 & 0.118 \\
\hline Part of a Group (0/1) & 1378 & 0.66 & & 0.474 & 101 & 0.446 & & 0.5 & 1277 & 0.677 & & 0.468 \\
\hline Introduced firm novelties $(0 / 1)$ & 1150 & 0.546 & & 0.498 & 89 & 0.662 & & 0.475 & 1061 & 0.537 & & 0.498 \\
\hline Introduced Market novelties $(0 / 1)$ & 1154 & 0.517 & & 0.499 & 89 & 0.651 & & 0.479 & 1065 & 0.506 & & 0.5 \\
\hline Introduced firm novelties but no market novelties & 1132 & 0.206 & & 0.405 & 87 & 0.184 & & 0.389 & 1045 & 0.208 & & 0.406 \\
\hline
\end{tabular}


Table 2a: YICs and appropriation strategies - use

\begin{tabular}{llllllllll}
\hline & & \multicolumn{9}{c}{ Other } & & \multicolumn{2}{c}{ Mean Difference } \\
& & & \multicolumn{3}{c}{} & & & & \\
& YICs & Use & s.d & Innov & Use & s.d. & \multicolumn{2}{c}{ YICs-other innov. } \\
\hline Formal protection & 101 & $\mathbf{6 4 . 4 \%}$ & 0.481 & 1242 & $\mathbf{5 5 . 4 \%}$ & 0.497 & 0.090 & $*$ \\
- Patent & 97 & $\mathbf{3 9 . 2 \%}$ & 0.491 & 1217 & $\mathbf{3 8 . 6 \%}$ & 0.487 & 0.006 & \\
- Utility model & 93 & $\mathbf{1 2 . 9 \%}$ & 0.337 & 1171 & $\mathbf{2 9 . 6 \%}$ & 0.457 & -0.167 & $* * *$ \\
- Design & 93 & $\mathbf{3 . 2 \%}$ & 0.178 & 1143 & $\mathbf{7 . 0 \%}$ & 0.255 & -0.038 & \\
- Trademark & 98 & $\mathbf{4 2 . 9 \%}$ & 0.497 & 1180 & $\mathbf{3 1 . 4 \%}$ & 0.464 & 0.114 & $* *$ \\
- Copyright & 96 & $\mathbf{1 2 . 5 \%}$ & 0.332 & 1140 & $\mathbf{1 4 . 8 \%}$ & 0.355 & -0.023 & \\
Informal protection & 101 & $\mathbf{8 4 . 2 \%}$ & 0.367 & 1201 & $\mathbf{6 9 . 4 \%}$ & 0.461 & 0.148 & $* * *$ \\
- Secrecy & 99 & $\mathbf{7 5 . 8 \%}$ & 0.431 & 1169 & $\mathbf{5 5 . 1 \%}$ & 0.498 & 0.207 & $* * *$ \\
- Complexity & 95 & $\mathbf{3 0 . 5 \%}$ & 0.463 & 1119 & $\mathbf{2 6 . 1 \%}$ & 0.439 & 0.044 & \\
- Lead time & 99 & $\mathbf{7 6 . 8 \%}$ & 0.424 & 1176 & $\mathbf{5 9 . 6 \%}$ & 0.491 & 0.172 & $* * *$ \\
\hline
\end{tabular}

$* * *, * *, *$ reflects significance at the $1 \%, 5 \%, 10 \%$ level

Table 2b: YICs and appropriation strategies: combining formal and informal

\begin{tabular}{lllll}
\hline & YICs & Other innovators & mean difference \\
\hline Only informal protection & $21.36 \%$ & $19.92 \%$ & $-1.44 \%$ & \\
Only formal protection & $1.94 \%$ & $6.43 \%$ & $4.49 \%$ & $*$ \\
Formal and informal protections & $61.17 \%$ & $44.42 \%$ & $-16.75 \%$ & $* * *$ \\
No protection & $13.59 \%$ & $22.09 \%$ & $8.50 \%$ & $* *$ \\
\hline
\end{tabular}

$* * *, * *, *$ reflects significance at the $1 \%, 5 \%, 10 \%$ level

Table 3: Innovation Profile of YICs

\begin{tabular}{llllllll} 
& & \multicolumn{7}{c}{ YICs } & Other innovators \\
\hline & Label & Mean & s.d. & Mean & s.d. & Difference \\
\hline Basicness (score) & BASIC & $\mathbf{0 . 8 1 4}$ & 0.48 & $\mathbf{0 . 6 1 2}$ & 0.297 & -0.202 & $* * *$ \\
Risk (score) & HRISK & $\mathbf{2 . 1 1 7}$ & 0.937 & $\mathbf{1 . 7 2}$ & 0.993 & -0.397 & $* * *$ \\
Lack of external funding (score) & HFIN & $\mathbf{2 . 0 4 2}$ & 1.041 & $\mathbf{1 . 2 0 9}$ & 1.106 & -0.833 & $* * *$ \\
Difficulty of finding cooperation partners (score) & HPAR & $\mathbf{0 . 9 8 9}$ & 0.898 & $\mathbf{0 . 7 8 2}$ & 0.875 & -0.208 & $* *$ \\
Difficulty of finding qualified personnel (score) & HPER & $\mathbf{1 . 0 7 4}$ & 0.097 & $\mathbf{1 . 1 6 7}$ & 0.026 & -0.092 & \\
Export (0/1) & EXPORT & $\mathbf{0 . 6 6 6}$ & 0.051 & $\mathbf{0 . 7 1 2}$ & 0.013 & -0.045 \\
Received R\&D subsidies (0/1) & SUBSIDY & $\mathbf{0 . 4 5 0}$ & 0.05 & $\mathbf{0 . 2 0 5}$ & 0.011 & 0.244 \\
Acquisition of innovative machineries and equipment (0/1) & MACHEQU & $\mathbf{0 . 8 4 3}$ & 0.037 & $\mathbf{0 . 8 0 1}$ & 0.011 & 0.042 \\
\hline$* * * * *, *$ reflects significance at the 1\%, 5\%, 10\% level. “Score" indicates that the variables are expressed on a scale from 0 to 3
\end{tabular}


Table 4a: Probit models of appropriation choice

\begin{tabular}{|c|c|c|c|c|c|c|c|c|}
\hline & (1) & & (2) & & (3) & & (4) & \\
\hline VARIABLES & $\mathrm{dy} / \mathrm{dx}$ & se & $\mathrm{dy} / \mathrm{dx}$ & se & $\mathrm{dy} / \mathrm{dx}$ & se & $\mathrm{dy} / \mathrm{dx}$ & se \\
\hline $\log ($ age $)$ & -0.008 & $(0.012)$ & -0.009 & $(0.013)$ & -0.008 & $(0.012)$ & -0.010 & $(0.013)$ \\
\hline Log(employment) & $0.059 * * *$ & $(0.007)$ & $0.047 * * *$ & $(0.009)$ & $0.058 * * *$ & $(0.007)$ & $0.046^{* * *}$ & $(0.008)$ \\
\hline$R \& D$ intensity & 0.137 & (0.099) & 0.040 & $(0.086)$ & 0.072 & (0.099) & 0.002 & $(0.038)$ \\
\hline BASIC (z-score) & & & 0.013 & $(0.013)$ & & & 0.013 & $(0.013)$ \\
\hline HRISK (z-score) & & & 0.020 & $(0.013)$ & & & 0.020 & $(0.013)$ \\
\hline HFIN (z-score) & & & 0.020 & $(0.014)$ & & & 0.019 & $(0.014)$ \\
\hline HPAR (z-score) & & & 0.002 & $(0.013)$ & & & 0.002 & $(0.013)$ \\
\hline HPER (z-score) & & & -0.002 & $(0.012)$ & & & -0.001 & $(0.012)$ \\
\hline EXPORT & & & $0.117 * * *$ & $(0.033)$ & & & $0.119 * * *$ & $(0.033)$ \\
\hline SUBSIDY & & & $0.099 * * *$ & $(0.030)$ & & & $0.098 * * *$ & $(0.030)$ \\
\hline MACHEQU & & & 0.013 & $(0.029)$ & & & 0.016 & $(0.029)$ \\
\hline Group & $0.060 * *$ & $(0.024)$ & $0.084 * * *$ & $(0.027)$ & $0.061 * *$ & $(0.024)$ & $0.085 * * *$ & $(0.027)$ \\
\hline YICs & $0.102 * * *$ & $(0.038)$ & 0.073 & $(0.046)$ & & & & \\
\hline YICs High R\&D & & & & & $0.163 * * *$ & $(0.040)$ & $0.154 * * *$ & $(0.044)$ \\
\hline YICs Low R\&D & & & & & 0.060 & $(0.049)$ & 0.018 & $(0.061)$ \\
\hline Observations & 1,284 & & 1,006 & & 1,284 & & 1,006 & \\
\hline
\end{tabular}

Table 4b: Bivariate probit - Formal and informal IP mechanisms

\begin{tabular}{|c|c|c|c|c|}
\hline \multirow[b]{2}{*}{ VARIABLES } & \multicolumn{2}{|c|}{$\begin{array}{c}(1) \\
\text { Formal }\end{array}$} & \multicolumn{2}{|c|}{$\begin{array}{c}(2) \\
\text { Informal }\end{array}$} \\
\hline & $\mathrm{dy} / \mathrm{dx}$ & se & $\mathrm{dy} / \mathrm{dx}$ & se \\
\hline Log(age) & -0.001 & $(0.015)$ & $-0.025^{*}$ & $(0.014)$ \\
\hline Log(employment) & $0.076^{* * *}$ & $(0.010)$ & $0.052 * * *$ & $(0.009)$ \\
\hline R\&D intensity & $0.195 *$ & $(0.113)$ & 0.189 & $(0.121)$ \\
\hline BASIC (z-score) & $0.033 * *$ & $(0.015)$ & -0.003 & $(0.014)$ \\
\hline HRISK (z-score) & 0.019 & $(0.015)$ & 0.018 & $(0.014)$ \\
\hline HFIN (z-score) & 0.008 & $(0.016)$ & -0.008 & $(0.015)$ \\
\hline HPAR (z-score) & $0.026^{*}$ & $(0.015)$ & 0.018 & $(0.014)$ \\
\hline HPER (z-score) & -0.018 & $(0.014)$ & -0.001 & $(0.013)$ \\
\hline Group & $0.091 * * *$ & $(0.032)$ & $0.076 * * *$ & $(0.029)$ \\
\hline EXPORT & $0.156^{* * *}$ & $(0.040)$ & $0.107 * * *$ & $(0.036)$ \\
\hline SUBSIDY & $0.085 * *$ & $(0.036)$ & $0.102 * * *$ & $(0.033)$ \\
\hline MACHEQU & -0.024 & $(0.034)$ & $0.066 * *$ & $(0.033)$ \\
\hline YICs & $0.115 * *$ & $(0.057)$ & $0.117 * *$ & $(0.052)$ \\
\hline Observations & & & 06 & \\
\hline Rho & & & $7 * * *$ & \\
\hline
\end{tabular}


Table 4c: Multinomial logit model of appropriation choice

\begin{tabular}{lllllllll}
\hline & \multicolumn{2}{c}{ No appropriation } & \multicolumn{2}{c}{ Formal only } & \multicolumn{2}{c}{ Informal only } & \multicolumn{2}{c}{ Both formal and informal } \\
VARIABLES & dy/dx & s.e. & dy/dx & s.e. & dy/dx & s.e. & dy/dx & s.e. \\
\hline Log(age) & 0.009 & $(0.013)$ & $0.017^{*}$ & $(0.009)$ & -0.008 & $(0.014)$ & -0.018 & $(0.015)$ \\
Log(employment) & $-0.046^{* * *}$ & $(0.009)$ & -0.004 & $(0.006)$ & $-0.028^{* * *}$ & $(0.009)$ & $0.078^{* * *}$ & $(0.010)$ \\
R\&D intensity & 0.032 & $(0.104)$ & -0.194 & $(0.128)$ & -0.177 & $(0.128)$ & $0.340^{* * *}$ & $(0.126)$ \\
BASIC (z-score) & -0.013 & $(0.014)$ & $0.015^{*}$ & $(0.008)$ & -0.023 & $(0.015)$ & 0.020 & $(0.015)$ \\
HRISK (z-score) & -0.020 & $(0.013)$ & 0.002 & $(0.009)$ & -0.000 & $(0.014)$ & 0.018 & $(0.015)$ \\
HFIN (z-score) & -0.018 & $(0.014)$ & $0.023^{* *}$ & $(0.009)$ & 0.012 & $(0.015)$ & -0.017 & $(0.017)$ \\
HPAR (z-score) & -0.002 & $(0.013)$ & -0.015 & $(0.009)$ & $-0.023 *$ & $(0.014)$ & $0.040^{* * *}$ & $(0.015)$ \\
HPER (z-score) & 0.001 & $(0.012)$ & -0.001 & $(0.008)$ & 0.016 & $(0.013)$ & -0.017 & $(0.014)$ \\
Group & $-0.079 * * *$ & $(0.026)$ & 0.007 & $(0.018)$ & -0.012 & $(0.028)$ & $0.085^{* * *}$ & $(0.032)$ \\
EXPORT & $-0.120^{* * *}$ & $(0.034)$ & 0.015 & $(0.021)$ & -0.043 & $(0.036)$ & $0.147 * * *$ & $(0.040)$ \\
SUBSIDY & $-0.103 * * *$ & $(0.031)$ & -0.008 & $(0.021)$ & 0.020 & $(0.037)$ & $0.091 * *$ & $(0.037)$ \\
MACHEQU & -0.013 & $(0.029)$ & $-0.050^{* *}$ & $(0.023)$ & 0.034 & $(0.031)$ & 0.028 & $(0.035)$ \\
YICs & $-0.081^{*}$ & $(0.047)$ & -0.044 & $(0.030)$ & -0.017 & $(0.055)$ & $0.142^{* *}$ & $(0.060)$ \\
Observations & & & & & & & & \\
\hline
\end{tabular}

Table 5a: Multivariate probit on appropriation mode choice

\begin{tabular}{|c|c|c|c|c|c|c|c|c|c|c|c|c|}
\hline & \multicolumn{3}{|c|}{ Patent } & \multicolumn{3}{|c|}{ Secrecy } & \multicolumn{3}{|c|}{ Lead Time } & \multicolumn{3}{|c|}{ Trademark } \\
\hline & coef. & & s.e. & coef. & & s.e. & coef. & & s.e. & coef. & & s.e. \\
\hline $\log ($ age $)$ & -0.033 & & 0.056 & -0.094 & $*$ & 0.051 & -0.120 & ** & 0.050 & -0.069 & & 0.051 \\
\hline $\log ($ employment $)$ & 0.381 & $* * *$ & 0.040 & 0.182 & $* * *$ & 0.034 & 0.174 & $* * *$ & 0.034 & 0.210 & $* * *$ & 0.034 \\
\hline$R \& D$ intensity & 1.107 & $* *$ & 0.450 & 0.474 & & 0.395 & 0.850 & $*$ & 0.441 & 0.771 & $* *$ & 0.376 \\
\hline BASIC (z-score) & 0.087 & & 0.056 & 0.013 & & 0.051 & -0.072 & & 0.050 & 0.111 & $* *$ & 0.052 \\
\hline HRISK (z-score) & -0.005 & & 0.059 & 0.076 & & 0.052 & 0.090 & $*$ & 0.051 & 0.005 & & 0.053 \\
\hline HFIN (z-score) & 0.103 & $*$ & 0.061 & 0.050 & & 0.057 & -0.019 & & 0.056 & 0.062 & & 0.057 \\
\hline HPAR (z-score) & 0.072 & & 0.056 & 0.077 & & 0.051 & 0.066 & & 0.050 & 0.018 & & 0.052 \\
\hline HPER (z-score) & -0.061 & & 0.053 & 0.009 & & 0.048 & -0.037 & & 0.047 & -0.018 & & 0.048 \\
\hline Group & -0.008 & & 0.120 & 0.177 & $*$ & 0.104 & 0.208 & $* *$ & 0.102 & 0.257 & $* * *$ & 0.111 \\
\hline EXPORT & 0.605 & $* * *$ & 0.153 & 0.263 & $* *$ & 0.122 & 0.322 & $* * *$ & 0.121 & 0.268 & $* *$ & 0.133 \\
\hline SUBSIDY & 0.496 & $* * *$ & 0.128 & 0.344 & $* * *$ & 0.125 & 0.409 & $* * *$ & 0.125 & 0.074 & & 0.119 \\
\hline MACHEQU & 0.246 & $*$ & 0.140 & 0.371 & $* * *$ & 0.120 & 0.175 & & 0.117 & 0.075 & & 0.127 \\
\hline YICs & 0.084 & & 0.235 & 0.519 & $* *$ & 0.225 & 0.297 & & 0.226 & 0.270 & & 0.213 \\
\hline Constant & -3.861 & $* * *$ & 0.528 & -1.587 & $* * *$ & 0.436 & -1.100 & $* * *$ & 0.425 & -1.087 & $* * *$ & 0.427 \\
\hline
\end{tabular}


Table 5b: Marginal effects of YICs on appropriation mode choice

\begin{tabular}{lc}
\hline Mode & $\begin{array}{c}\text { Marg. Effect } \\
\text { of } \text { YICs }\end{array}$ \\
\hline Patent & 0.021 \\
Secrecy & 0.156 \\
Lead time & 0.094 \\
Trademark & 0.087
\end{tabular}

Table 6a: Bivariate probit - formal protection and secrecy; big innovators

\begin{tabular}{|c|c|c|c|c|}
\hline \multirow[b]{2}{*}{ VARIABLES } & \multicolumn{2}{|c|}{ Formal protection } & \multicolumn{2}{|c|}{ Secrecy } \\
\hline & $\mathrm{dy} / \mathrm{dx}$ & se & $\mathrm{dy} / \mathrm{dx}$ & $\mathrm{Se}$ \\
\hline $\log ($ age $)$ & -0.000 & $(0.017)$ & 0.001 & $(0.018)$ \\
\hline $\log ($ employment $)$ & $0.052 * * *$ & $(0.011)$ & $0.022 *$ & $(0.011)$ \\
\hline R\&D intensity & 0.195 & $(0.149)$ & 0.095 & $(0.146)$ \\
\hline BASIC (z-score) & $0.030 *$ & $(0.017)$ & -0.006 & $(0.018)$ \\
\hline HRISK (z-score) & 0.019 & $(0.018)$ & -0.002 & $(0.018)$ \\
\hline HFIN (z-score) & -0.017 & $(0.018)$ & -0.002 & $(0.020)$ \\
\hline HPAR (z-score) & 0.011 & $(0.017)$ & 0.026 & $(0.018)$ \\
\hline HPER (z-score) & -0.018 & $(0.015)$ & 0.013 & $(0.016)$ \\
\hline Group & 0.024 & $(0.036)$ & 0.019 & $(0.037)$ \\
\hline EXPORT & $0.118 * *$ & $(0.051)$ & -0.009 & $(0.046)$ \\
\hline SUBSIDY & 0.031 & $(0.037)$ & $0.073 *$ & $(0.038)$ \\
\hline MACHEQU & -0.050 & $(0.037)$ & $0.091 * *$ & $(0.045)$ \\
\hline BigInnov & $0.063 *$ & $(0.034)$ & $0.058 *$ & $(0.034)$ \\
\hline BigInnov YICs & 0.026 & $(0.076)$ & $0.135^{* *}$ & $(0.060)$ \\
\hline Non-BigInnov YICs & 0.030 & $(0.096)$ & -0.012 & $(0.121)$ \\
\hline Observations & & & & \\
\hline
\end{tabular}


Table 6b. Multinomial model of appropriation choice of YICs: by "size of the innovation"

\begin{tabular}{lcccccccc}
\hline & \multicolumn{2}{c}{ Formal protection } & \multicolumn{2}{c}{ secrecy } & \multicolumn{2}{c}{ Formal and secrecy } & \multicolumn{2}{c}{ Other } \\
VARIABLES & $\mathrm{dy} / \mathrm{dx}$ & $\mathrm{se}$ & $\mathrm{dy} / \mathrm{dx}$ & $\mathrm{se}$ & $\mathrm{dy} / \mathrm{dx}$ & $\mathrm{se}$ & $\mathrm{dy} / \mathrm{dx}$ & $\mathrm{se}$ \\
\hline & & & & & & & & \\
Log(age) & 0.013 & $(0.016)$ & 0.012 & $(0.017)$ & -0.011 & $(0.019)$ & -0.013 & $(0.014)$ \\
Log(employment) & -0.001 & $(0.010)$ & $-0.031^{* * *}$ & $(0.011)$ & $0.053^{* * *}$ & $(0.012)$ & -0.020 & $(0.019)$ \\
R\&D intensity & -0.052 & $(0.146)$ & -0.148 & $(0.143)$ & 0.202 & $(0.159)$ & -0.003 & $(0.122)$ \\
BASIC (z-score) & 0.014 & $(0.016)$ & $-0.031^{*}$ & $(0.018)$ & 0.017 & $(0.019)$ & -0.000 & $(0.013)$ \\
HRISK (z-score) & 0.011 & $(0.017)$ & -0.011 & $(0.017)$ & 0.009 & $(0.020)$ & -0.009 & $(0.013)$ \\
HFIN (z-score) & 0.013 & $(0.018)$ & 0.026 & $(0.017)$ & -0.028 & $(0.021)$ & -0.011 & $(0.014)$ \\
HPAR (z-score) & $-0.035^{* *}$ & $(0.017)$ & -0.014 & $(0.016)$ & $0.044 * *$ & $(0.019)$ & 0.005 & $(0.013)$ \\
HPER (z-score) & -0.002 & $(0.015)$ & $0.027 *$ & $(0.015)$ & -0.016 & $(0.017)$ & -0.009 & $(0.047)$ \\
Group & $-0.068^{*}$ & $(0.037)$ & $-0.068^{*}$ & $(0.034)$ & $0.097 * *$ & $(0.042)$ & 0.038 & $(0.026)$ \\
EXPORT & 0.015 & $(0.043)$ & $-0.104 * *$ & $(0.048)$ & $0.109 * *$ & $(0.056)$ & -0.020 & $(0.035)$ \\
SUBSIDY & -0.027 & $(0.036)$ & 0.023 & $(0.037)$ & 0.049 & $(0.041)$ & -0.044 & $(0.142)$ \\
MACHEQU & $-0.107 * *$ & $(0.043)$ & 0.034 & $(0.035)$ & 0.058 & $(0.047)$ & 0.015 & $(0.048)$ \\
BigInnov & -0.034 & $(0.031)$ & -0.036 & $(0.032)$ & $0.092^{* *}$ & $(0.037)$ & -0.022 & $(0.030)$ \\
BigInnov YICs & -0.085 & $(0.060)$ & 0.049 & $(0.079)$ & $0.096 *$ & $(0.050)$ & -0.059 & $(0.132)$ \\
Non-BigInnov YICs & -0.026 & $(0.110)$ & -0.045 & $(0.084)$ & 0.066 & $(0.118)$ & 0.004 & $(0.047)$ \\
& & & & & & & &
\end{tabular}

